entertaining or the didactic with its compelling, disturbing narrative of archetypal greed and redemption. The end of the Victorian era is represented by the whimsical In Fairyland (1875), first published 1870, by William Allingham (1824-89) and illustrated by Richard Doyle. Housed in Rare Books, this poem was one of the initiators of the trend for "Fairie" verse which continued well into the 20 th century.

Within the scope of this note it has only been possible to touch upon four genres: horn-books, books of instruction, stories pre- 1850 and poetry. These are representative of the wealth and breadth of early children's books in the McGill University Libraries. Hidden treasures such as the fine chapbook collection, works of famous illustrators, early children's periodicals, and adventure stories, to name but a few, deserve further attention, and will be highlighted in future research.

\title{
References
}

Carpenter, Humphrey and Mari Prichard. The Oxford Companion to Cbildren's Literature. Oxford: Oxford University Press, 1984.

Darton, F. J. Harvey. Children's Books in England; Five Centuries of Social Life. 3rd ed. Cambridge: Cambridge University Press, 1982.

Osborne Collection of Early Children's Books, 1566-1910; a Catalogue. 2 vols. Toronto: Toronto Public Library, 1975.

Quayle, Eric. Early Children's Books: A Collector's Guide. Newton Abbot, Devon: David and Charles, 1983.

Tuer, Andrew W. History of the Horn Book. New York: Benjamin Blom, 1968.

\section{A Portrait of Mary Todd Ferrier}

\author{
by Conrad E. W. Graham
}

Registrar, McCord Museum of Canadian History

Mary Todd Ferrier (1799-1881)

oil on canvas, 1828

size: $76.2 \times 63.5 \mathrm{~cm}$.

inscribed on reverse: "Aged 28, 1828" artist: attributed to Levi Stevens (d. 1832)

purchase: Sorheby's Auction, Toronto, April 4, 1990

ex collection: John L. Russell

McCord Museum of Canadian History: M990.676.1

The portrait of Mary Todd Ferrier was purchased for the McCord collection at Sotheby's in Toronto on April 4, 1990. The acquisition of this portrait permitted the museum to re-unite a pair of portraits; as the portrait of her husband the Hon. James Ferrier (1800-1888)), Chancellor of McGill University (1845-52) was already in the collection (M989X.76).

The painting shows a $3 / 4$ face, waist to head portrait of a woman with a white gauze bonnet and wearing coral drop earrings. Her dress is black and rather severe but reflects the fashionable dress of the late 1820 s. 
Notes and Comments

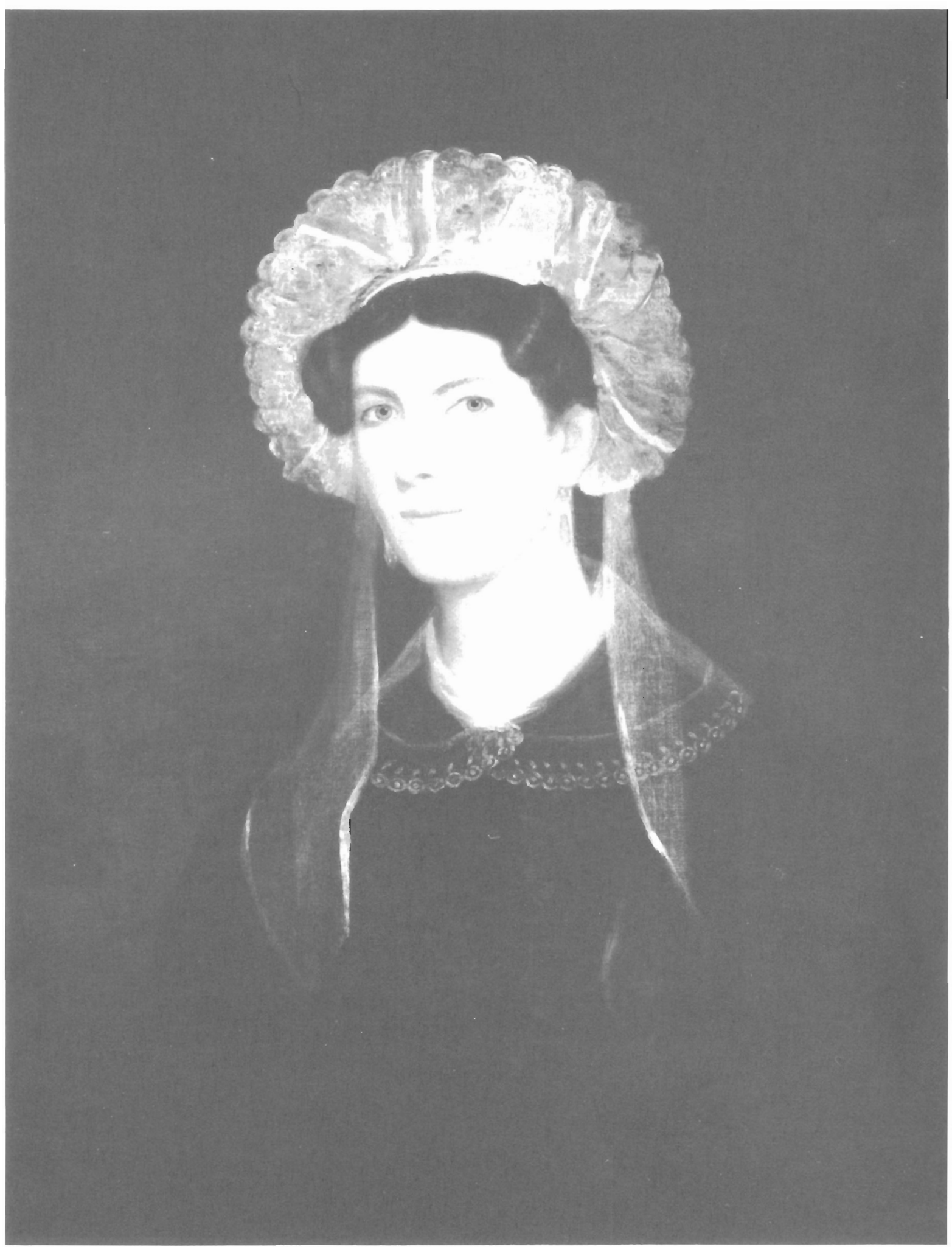

